\title{
Effects of substrate and water depth of a eutrophic pond on the physiological status of a submerged plant, Vallisneria natans
}

\author{
Aimin Hao ${ }^{1}$, Sohei Kobayashi ${ }^{\text {Corresp., }}{ }^{1}$, Huilin Huang ${ }^{1}$, Qi Mi ${ }^{1}$, Yasushi Iseri ${ }^{1}$ \\ ${ }^{1}$ College of Life and Environmental Sciences, Wenzhou University, Wenzhou, Zhejiang, China \\ Corresponding Author: Sohei Kobayashi \\ Email address: koba@wzu.edu.cn
}

Effects of substrate and water depth on the physiological status of a submerged macrophyte, Vallisneria natans (Lour.) H.Hara, were determined by measuring biomarkers in leaves and roots, to understand factors limiting the re-establishment of $V$. natans in urban eutrophic ponds. Ramets of $V$. natans were grown in the laboratory using aquaria containing water and bottom mud from a eutrophic pond and maintained under sufficient light in an incubator. The growth and chlorophyll-a (Chl-a) content of leaves were greater in aquaria with mud than in those with sand, which was used as the reference substrate. The contents of a peroxidation product [malondialdehyde (MDA)] and three antioxidant enzymes [superoxide dismutase (SOD), catalase (CAT), and peroxidase (POD)] in leaves and roots, used as stress biomarkers, changed during the experiment, although differences in these contents between mud and sand were not consistent across the experimental days. To control water depth in the field, ramets of $V$. natans were grown in cages with different substrates (mud and sand) installed at different depths $(0.5,1.2$, and $2.0 \mathrm{~m}$ ) in the pond. The mean light quantum during the experiment decreased with increasing depth, from $79.3 \mu \mathrm{mol} / \mathrm{m}^{2} \mathrm{~s}$ at $0.5 \mathrm{~m}$ to $7.9 \mu \mathrm{mol} / \mathrm{m}^{2} \mathrm{~s}$ at $2.0 \mathrm{~m}$. The Chl-a content in leaves decreased, whereas the MDA content in both leaves and roots increased with increasing water depth. All enzyme activities increased at the beginning and then decreased to the end of the experiment at $2.0 \mathrm{~m}$ depth, suggesting deterioration of enzyme activities due to depth-related stress. The MDA content and CAT activity were higher for sand than for mud, whereas the difference in the growth and the leaf Chl-a content between substrates remained unclear in the pond. On comparing the laboratory and field experiments, the leaf Chl-a content was found to be lower and the MDA content and enzyme activities exhibited sharp increase for ramets grown in the pond, even at 0.5 $m$ depth, when compared with those grown in the aquaria. Our results suggest that the bottom mud of the pond is not the major limiting factor in the re-establishment of $V$. 
natans. Because water depth and light attenuation exerted strong stress on V. natans, shallow areas or measures to improve water transparency are required to promote the introduction of $V$. natans in eutrophic ponds for successful restoration in urban areas. 
1 Effects of substrate and water depth of a eutrophic

2 pond on the physiological status of a submerged

3 plant, Vallisneria natans

4

5

6

7

8

Aimin $\mathrm{Hao}^{1}$, Sohei Kobayashi², Huilin Huang ${ }^{3}$, Qi Mi ${ }^{4}$, Yasushi Iseri ${ }^{5}$

${ }^{1}$ College of Life and Environmental Sciences, Wenzhou University, Wenzhou, Zhejiang, China

${ }^{2}$ College of Life and Environmental Sciences, Wenzhou University, Wenzhou, Zhejiang, China

${ }^{3}$ College of Life and Environmental Sciences, Wenzhou University, Wenzhou, Zhejiang, China

${ }^{4}$ College of Life and Environmental Sciences, Wenzhou University, Wenzhou, Zhejiang, China

${ }^{5}$ College of Life and Environmental Sciences, Wenzhou University, Wenzhou, Zhejiang, China

Corresponding Author:

Sohei Kobayashi ${ }^{2}$

Chashan Academic Town, Ouhai, Wenzhou, Zhejiang, China

Email address:koba@wzu.edu.cn

\section{Abstract}

Effects of substrate and water depth on the physiological status of a submerged macrophyte, Vallisneria natans (Lour.) H.Hara, were determined by measuring biomarkers in leaves and roots, to understand factors limiting the re-establishment of $V$. natans in urban eutrophic ponds. Ramets of $V$. natans were grown in the laboratory using aquaria containing water and bottom mud from a eutrophic pond and maintained under sufficient light in an incubator. The growth and chlorophyll-a (Chl-a) content of leaves were greater in aquaria with mud than in those with sand, which was used as the reference substrate. The contents of a peroxidation product [malondialdehyde (MDA)] and three antioxidant enzymes [superoxide dismutase (SOD), catalase (CAT), and peroxidase (POD)] in leaves and roots, used as stress biomarkers, changed during the experiment, although differences in these contents between mud and sand were not consistent across the experimental days. To control water depth in the field, ramets of $V$. natans were grown in cages with different substrates (mud and sand) installed at different depths $(0.5$, 1.2 , and $2.0 \mathrm{~m}$ ) in the pond. The mean light quantum during the experiment decreased with increasing depth, from $79.3 \mu \mathrm{mol} / \mathrm{m}^{2} \mathrm{~s}$ at $0.5 \mathrm{~m}$ to $7.9 \mu \mathrm{mol} / \mathrm{m}^{2} \mathrm{~s}$ at $2.0 \mathrm{~m}$. The Chl-a content in leaves decreased, whereas the MDA content in both leaves and roots increased with increasing water depth. All enzyme activities increased at the beginning and then decreased to the end of the experiment at $2.0 \mathrm{~m}$ depth, suggesting deterioration of enzyme activities due to depth-related stress. The MDA content and CAT activity were higher for sand than for mud, whereas the difference in the growth and the leaf Chl-a content between substrates remained unclear in the pond. On comparing the laboratory and field experiments, the leaf Chl-a content was found to be lower and the MDA content and enzyme activities exhibited sharp increase for ramets grown in 
40 the pond, even at $0.5 \mathrm{~m}$ depth, when compared with those grown in the aquaria. Our results

41 suggest that the bottom mud of the pond is not the major limiting factor in the re-establishment

42 of $V$. natans. Because water depth and light attenuation exerted strong stress on $V$. natans,

43 shallow areas or measures to improve water transparency are required to promote the

44 introduction of $V$. natans in eutrophic ponds for successful restoration in urban areas.

45

46

47

48

49

50

51

52

53

54

55

56

57

58

59

60

61

62

63

64

65

66

67

68

69

70

71

72

73

74

75

76

77

78

79

\section{Introduction}

Urban ponds often suffer from eutrophication (Harper 1992, Grimm et al. 2008, Smith and Schindler 2009). In closed aquatic ecosystems with less renewal of water, excessive nutrient input immediately leads to the overgrowth of phytoplankton. Oxygen depletion is particularly severe at the bottom of such aquatic ecosystems because of respiration by overabundant phytoplankton, decomposition of accumulated organic matter, and limited benthic photosynthesis due to reduced light transparency. Such hypoxic conditions result in the exclusion of animals, such as fish and other aerobic organisms, from the bottom. Submerged plants are often used to improve the ecological status of eutrophic aquatic environments because of their ability to absorb nutrients (Qiu et al. 2001, Hilt et al. 2006, Sayer et al. 2010). Vallisneria natans (Lour.) H.Hara is a submerged rooted plant, which is widely distributed in freshwater habitats across the Asia and Australia (Lowden 1982). Owing to its adaptability to a wide range of temperatures and substrates (Xiong and Li 2000, Xie et al. 2005, Ke and Li 2006), ability to absorb significant amounts of nutrients (Wang et al. 2017, Xing et al. 2018), and allelopathic effects on phytoplankton (Xian et al. 2006), V. natans has been used to restore many urban ponds (Yan et al. 1997, Qiu et al., 2001).

Despite their potential to improve degraded aquatic ecosystems, submerged plants, including $V$. natans, have been declining in many freshwater bodies due to habitat degradation (Hilt et al. 2006, Cao et al. 2007, Qin et al. 2013). Restoration works in urban ponds often fail to re-establish stands of submerged plants because of the low survival rate of transplants. High concentrations of nutrients, such as $\mathrm{NH}_{4}{ }^{+}$, inhibit and impairs the growth of $V$. natans (Cao et al. 2007, Wang et al. 2008). Light availability, which is regulated by water depth and transparency, is the principal factor restricting the growth of $V$. natans in eutrophic aquatic environments (Xiao et al. 2007, Bai et al. 2015). Substrate quality in terms of texture and chemistry has also been shown to affect $V$. natans (Xie et al. 2005, Li et al. 2012, Bai et al. 2015). In addition, organicrich mud under anaerobic conditions, which is typical at the bottom of eutrophic ponds, can inhibit the survival of submerged plants (Barko and Smart 1986, Wu et al. 2009, Silveila and Thomaz 2015). Physical disturbances, such as waves and currents in lakes and large water habitats (Madsen et al. 2001, Ellawala et al. 2013, Xu et al. 2016), can also be a key on the survival of submerged plants. Elucidating the factors limiting the survival of submerged plants is required for effective restoration of urban ponds.

Plants under stress exhibit physiological changes in their cells and organs. Chlorophyll (Chl) is a pigment that absorbs solar energy and accelerates photosynthesis, and its content in leaf tissues is often used as an indicator of photosynthetic ability and plant health. Chl-a absorbs 
80 light in the blue and red regions and is the primary photosynthetic pigment, whereas Chl-b

81 absorbs light in slightly different regions and is an accessory pigment supporting Chl-a. Stressful

82 conditions increase the accumulation of reactive oxygen species (ROS), such as superoxide

83 radicals $\left(\mathrm{O}_{2}^{-}\right)$, hydroxyl radicals $\left(\mathrm{OH}^{-}\right)$, and hydrogen peroxide $\left(\mathrm{H}_{2} \mathrm{O}_{2}\right)$, which can damage cell

84 organelles. Products of lipid peroxidation induced by ROS, such as malondialdehyde (MDA), are

85 also harmful to cell organelles. ROS accumulation can be controlled by antioxidant enzymes

86 such as superoxide dismutase (SOD), catalase (CAT), and peroxidase (POD). Although the

87 activities of such enzymes increase with ROS, excessive accumulation of ROS and oxidative

88 compounds in cells can reduce their activities, ultimately leading to apoptosis. These

89 peroxidation products and enzyme activities have been used as indicators of stress caused by

90 toxic chemicals or low nutrient availability in $V$. natans (Wang et al. 2008, Hao et al. 2011,

91 Wang et al. 2012, Song et al. 2015).

92 To promote ecosystem restoration of urban ponds by introducing $V$. natans, we examined 93 the water quality of an urban pond in Wenzhou City, China, and the effects of water, bottom

$94 \mathrm{mud}$, and pond depth on the physiological status of $V$. natans by in vitro and in situ experiments.

95 We measured the Chl-a and Chl-b contents of leaves as indicators of plant health and of MDA,

96 SOD, CAT, and POD in leaves and roots as indicators of stress.

97

98

99

100

101

102

103

104

105

106

107

108

109

110

111

112

113

114

115

116

117

118

119

\section{Materials \& Methods}

\section{Study site}

The study was conducted at Zhong Shan Park, approximately $1 \mathrm{~km}$ south of the Ou River, central Wenzhou City, China (Fig. 1). The study pond was approximately $300 \mathrm{~m}$ long in the north-south direction, $20 \mathrm{~m}$ wide in the east-west direction, and $2 \mathrm{~m}$ deep. Authorization of field surveys and experiments were given by the Wenzhou Science and Technology Bureau (Water Pollution Control and Treatment Technology Innovation Project under Wenzhou Science and Technology Plan Project: W20170002).

The pond has been restored repeatedly using $V$. natans, which was originally abundant in this area, since 2011. Although the water quality improved after planting $V$. natans, aquatic plants, including $V$. natans, died and disappeared after a few years. Subsequently, an aeration device was installed at the surface of the pond. Despite an improvement in dissolved oxygen (DO), the introduction of $V$. natans failed again in recent years. The bottom mud, which was organic-rich and anaerobic state, has been assumed as a cause of the failure because roots of the dead $V$. natans were dwarf and black-colored.

Our preliminary measurements of the pond water showed that the $\mathrm{pH}$ was $7.8-8.3$, DO was $6-10 \mathrm{mg} / \mathrm{L}$, water transparency was $0.2-0.3 \mathrm{~m}$, turbidity was $40-80$ nephelometric turbidity units (NTU), electric conductivity (EC) was $430-465 \mu \mathrm{s} / \mathrm{cm}$, total nitrogen (TN) and total phosphorus (TP) were $6.59-8.59 \mathrm{mg} / \mathrm{L}$ and $0.41-0.50 \mathrm{mg} / \mathrm{L}$, respectively, and the Chl-a concentration was 30-65 $\mu \mathrm{g} / \mathrm{L}$. The collected bottom mud was black and emitted anaerobic odors, exhibited a total organic carbon (TOC) of 15.4-17.1\%, and contained 6.0-7.6 mg of TN and 2.2-3.4 mg of TP per unit dry weight $\mathrm{g}$ of mud. The aeration device was located at the 
120

121

122

123

124

125

126

127

128

129

130

131

132

133

134

135

136

137

138

139

140

141

142

143

144

145

146

147

148

149

150

151

152

153

154

155

156

157

158

159

southern part of the pond (Fig. 1), where we surveyed the water quality and conducted the field experiment.

\section{Laboratory experiment}

The responses of $V$. natans to the mud and water of the pond were examined in the laboratory. The mud and water were collected from the pond a few days before the experiment. We used quartz sand $\left(\mathrm{SiO}_{2}:>95 \%\right.$, particle size: $\left.1-2 \mathrm{~mm}\right)$, free of organic matter and nutrients (hereafter we called sand), as the control substrate. Intact and fresh ramets of $V$. natans collected from a rural wetland were used. Five ramets were planted in a $500-\mathrm{mL}$ beaker with a 5 -cm layer of the substrate (either mud or sand) at the bottom. Three beakers with ramets were placed in an aquarium $\left(30 \times 30 \times 50 \mathrm{~cm}^{3}, 45 \mathrm{~L}\right)$ containing $30 \mathrm{~L}$ of pond water such that the entire propagule was submerged. Three aquaria containing a total of nine beakers and 45 ramets were used for each substrate type.

The aquaria were placed in an incubator maintained at a constant temperature of $25^{\circ} \mathrm{C}$, under a light intensity of 5000 lux, and light:dark photoperiod of $12 \mathrm{~h}: 12 \mathrm{~h}$ for $50 \mathrm{~d}$. For physiological measurements, leaves and roots were sampled from a ramet in each aquarium (i.e., $n=3$ for each substrate) every $10 \mathrm{~d}$, and then frozen and preserved at $-20^{\circ} \mathrm{C}$. A previously unsampled ramet was collected from each aquarium at the end of the experiment for measuring leaf length and number ( $n=3$ for each substrate). Water quality parameters, including temperature, $\mathrm{pH}$, and $\mathrm{DO}$, were measured using a multiparameter water quality meter (Hydrolab DS5X, OTT Hydromet GmbH, Kempten, Germany), and water was sampled for $\mathrm{N}$ and $\mathrm{P}$ analyses from each aquarium ( $n=3$ for each substrate) at the end of the experiment.

\section{Field experiment}

The responses of $V$. natans to different water depths $(0.5,1.2$, and $2.0 \mathrm{~m})$ were surveyed in the southern part of the pond. The mud of the pond and river coarse sand (particle size: $1-2 \mathrm{~mm}$ ), which was washed to remove organic matter, were used as substrates. The ramets of $V$. natans were planted uniformly in a mesh plastic cage $\left(40.0 \times 48.5 \times 67.5 \mathrm{~cm}^{3}\right)$ containing three rectangular trays $\left(10 \times 25 \times 38 \mathrm{~cm}^{3}\right)$ with a 7 -cm layer of the substrate (either mud or sand) (Fig. 2). A tiered structure was constructed in the pond using steel pipes, and three cages for each substrate type were placed at three different depths (0.5, 1.2, and $2.0 \mathrm{~m}$; Fig. 2).

The experiment commenced on May 11, 2019. The water quality of the pond was evaluated and the ramets of $V$. natans were sampled on $5,10,20$, and $30 \mathrm{~d}$ of the experiment. The vertical profile ( $0.1 \mathrm{~m}$ intervals) of water quality, including temperature, $\mathrm{pH}$, and $\mathrm{DO}$, was measured near the experimental site using the water quality meter. In addition, water samples $(500 \mathrm{~mL})$ were taken from each experimental depth $(0.5,1.2$, and $2.0 \mathrm{~m})$ for $\mathrm{N}$ and $\mathrm{P}$ analyses. The light quantum at each experimental depth was monitored continuously by installing a pocket-size photosynthetically-active radiation logger (DEFI2-L, JFE Advantech Co., Ltd., Nishinomiya, Japan). Water transparency was measured using a Secchi disk. For physiological measurements, leaves and roots were sampled from a ramet in each tray (i.e., $n=3$ for each 
160 depth and substrate combination). A previously unsampled ramet was collected from each tray at

161

162

163

164

165

166

167

168

169

170

171

172

173

174

175

176

177

178

179

180

181

182

183

184

185

186

187

188

189

190

191

192

193

194

195

196

197

198

199 the end of the experiment for measuring the leaf length and number $(n=3$ for each depth and substrate combination).

Water chemistry and biochemical measurements

Concentrations (mg/L) of N and P were determined according to the Surface Water Environment Quality Standard (GB 3838-2002) (State Environmental Protection Administration 2002). TN and TP were determined by ultraviolet spectrophotometry and the molybdenum blue method, respectively, after digestion of sampled water. Inorganic $\mathrm{N}\left(\mathrm{NH}_{4}{ }^{+}-\mathrm{N}, \mathrm{NO}_{3}-\mathrm{N}, \mathrm{NO}_{2}^{-}-\mathrm{N}\right)$ was determined by Nessler's reagent spectrophotometry and ultraviolet spectrophotometry. Chemical oxygen demand (COD) was determined using the potassium dichromate method.

Collected leaves and roots were cut, the surface water was removed using a paper, and the samples were then weighed to obtain the fresh weight. Approximately $2 \mathrm{~g}$ of samples were used for evaluating plant health and stress parameters. The Chl content was measured following Arnon (1949). Leaf samples were ground and homogenized with $80 \%$ acetone, $\mathrm{CaCO}_{3}$, and quartz sand and then centrifuged at $12000 \times \mathrm{g}$ for $10 \mathrm{~min}$. The supernatant was collected, and its absorbance was measured at 645 and $663 \mathrm{~nm}$. The concentrations of Chl-a and Chl-b were calculated using the following equations:

Chl-a $=12.7 A_{663}-2.69 A_{645}$

$\mathrm{Chl}-\mathrm{b}=22.9 A_{645}-4.68 A_{663}$

The concentrations were then converted to mg per unit $g$ of leaf fresh weight.

The MDA content was measured following Heath and Packer (1968). Leaf or root samples were ground and homogenized with $5 \%$ trichloroacetic acid and quartz sand and then centrifuged at $12000 \times \mathrm{g}$ at $4^{\circ} \mathrm{C}$ for $10 \mathrm{~min}$. Thiobarbituric acid $(2 \%)$ was added to the resulting supernatant and the solution was then heated in boiling water for $15 \mathrm{~min}$. After cooling to $20^{\circ} \mathrm{C}$, the solution was again centrifuged at $15000 \times g$ for $10 \mathrm{~min}$. The supernatant was collected and its absorbance was measured at 450,532, and $600 \mathrm{~nm}$. The concentration of MDA was calculated using the following equation:

$\mathrm{MDA}=6.45\left(A_{532}-A_{600}\right)-0.56 A_{450}$

The concentrations were then converted to nmol per unit $g$ of tissue fresh weight.

Prior to the measurement of enzyme activities (SOD, CAT, and POD), the leaf or root samples were ground and homogenized with $50 \mathrm{mM}$ sodium phosphate buffer solution ( $\mathrm{pH}$ 7.0) and quartz sand and centrifuged at $12000 \times g$ at $4{ }^{\circ} \mathrm{C}$ for $20 \mathrm{~min}$. The supernatant was collected immediately for enzyme activity measurements.

The SOD activity was assayed following Beauchamp and Fridovich (1971) and Li et al. (2002). The reaction solution was prepared by adding $0.1 \mathrm{~mL}$ each of $8 \mathrm{mM}$ hydroxylammonium chloride, $3.0 \mathrm{mM}$ EDTA-2Na, 0.15\% (w/v) bovine serum albumin (BSA), $8 \mathrm{mM}$ xanthene, and the enzyme extract to $1 \mathrm{~mL}$ phosphate buffer $(50 \mathrm{mM}, \mathrm{pH} 7.8)$. After adding $0.1 \mathrm{~mL}$ of xanthine oxidase, the reaction solution was heated for $40 \mathrm{~min}$ at $30^{\circ} \mathrm{C}$. One milliliter each of $1 \mathrm{~mL}$ of 20 $\mathrm{mM}$ sulfanilic acid and $10 \mathrm{mM} \mathrm{N}$-(1-naphthyl)ethylenediamine dihydrochloride were added to

PeerJ reviewing PDF | (2020:04:48470:2:0:NEW 23 Sep 2020) 
200 the resulting solution, which was then incubated at $25^{\circ} \mathrm{C}$ for $20 \mathrm{~min}$, and the absorbance was

201

202

203

204

205

206

207

208

209

210

211

212

213

214

215

216

217

218

219

220

221

222

223

224

225

226

227

228

229

230

231

232

233

234

235

236

237

238

239

measured at $545 \mathrm{~nm}$. One unit of SOD activity was defined as the amount of enzyme required for $50 \%$ inhibition of absorbance reduction.

The CAT activity was assayed following Greenfield and Price (1954). The production of $\mathrm{O}_{2}$ from a reaction solution containing $2 \mathrm{~mL}$ of $50 \mathrm{mM}$ phosphate buffer $(\mathrm{pH} \mathrm{7.0}), 1 \mathrm{~mL}$ of the enzyme extract, and $2 \mathrm{~mL}$ of $3 \% \mathrm{H}_{2} \mathrm{O}_{2}$ was measured by volumetry at normal pressure and $24^{\circ} \mathrm{C}$ for $1 \mathrm{~min}$. A unit of CAT activity was calculated by assuming $1 \mathrm{~cm}^{3}$ of $\mathrm{O}_{2}$ as equivalent to 0.041 mmol.

The POD activity was measured following Kochba et al. (1977). A $3 \mathrm{~mL}$ of a mixture of $50 \mathrm{mM}$ phosphate buffer ( $\mathrm{pH} 7.0$ ) and $20 \mathrm{mM}$ guaiacol was added to $0.5 \mathrm{~mL}$ of the enzyme extract to prepare the reaction solution. After adding $0.2 \mathrm{~mL}$ of $8 \mathrm{mM} \mathrm{H}_{2} \mathrm{O}_{2}$, the absorbance was measured at $470 \mathrm{~nm}$ for $1 \mathrm{~min}$.

\section{Statistical tests}

In the laboratory experiment, a split-plot analysis of variance (ANOVA) was performed for leaf Chl-a and Chl-b contents, with substrate (mud, sand) and experiment time (10, 20, 30, 40, $50 \mathrm{~d})$ as fixed factors and aquarium ( $n=3$ for each substrate) as a random factor. The contents of MDA, SOD, CAT, and POD in leaves and roots were analyzed by adding sampled organ (leaf, root) as a fixed factor in the ANOVA. Welch's two-sample $t$-test was used to assess differences in the length and number of leaves between mud and sand collected at the end of the experiment ( $n=3$ for each substrate).

In the field experiment, a split-plot ANOVA was performed for leaf Chl-a and Chl-b contents with depth $(0.5,1.2,2.0 \mathrm{~m})$, substrate (mud, sand), and experiment time (5, 10, 20, $30 \mathrm{~d})$ as fixed factors and tray ( $n=3$ for each depth and substrate combination) as a random factor. The contents of MDA, SOD, CAT, and POD were analyzed by adding sampled organ (leaf, root) as a fixed factor in the ANOVA. We focused mainly on the effects of substrate and depth, and their interaction with other factors to determine if the effects of substrate or depth varied according to other factors. A two-way ANOVA was done for the length and number of leaves with depth and substrate as fixed factors ( $n=3$ for each depth and substrate combination).

Spatio-temporal variation in water quality was also analyzed as a background condition of the experiment. A two-way ANOVA with depth (0.5, 1.2, $2.0 \mathrm{~m})$ and experiment time $(5,10,20,30$ d) as factors and without replication was performed for variables measured by the water quality meter (temperature, $\mathrm{pH}, \mathrm{DO}$, oxidation-reduction potential: ORP, EC, turbidity, and Chl-a concentration), light quantum, nutrients ( $\mathrm{TN}, \mathrm{TP}, \mathrm{NH}_{4}{ }^{+}-\mathrm{N}, \mathrm{NO}_{3}^{-}-\mathrm{N}$, and $\mathrm{NO}_{2}^{-}-\mathrm{N}$ ), and $\mathrm{COD}$ of the water samples. For variables measured by the water quality meter, data of the nearest five depths were averaged for each depth $(0.5,1.2,2.0 \mathrm{~m})$ on each experimental day. For all tests, an $\alpha$ value of 0.05 was used to determine the significance of effects. All statistical analyses were performed in R (version 3.6.3; R Development Core Team, Vienna, Austria), with "lme4" and "ImerTest" packages.

Peer) reviewing PDF | (2020:04:48470:2:0:NEW 23 Sep 2020) 


\section{Results}

241 Laboratory experiment

242 A temporal change was detected in the leaf Chl-a content $(\mathrm{mg} / \mathrm{g})$, and the effect of the

243 experiment time was significant (Fig. 3, Table 1). The Chl-a content increased slightly from 0 to

$244 \quad 10-20 \mathrm{~d}$ and then decreased. The decrease from 10-20 $\mathrm{d}$ to the end of the experiment was greater

245 in aquaria with sand than mud, and the effects of substrate and time $\times$ substrate interaction were

246 significant. Consequently, the Chl-a content at $50 \mathrm{~d}$ was $19 \%$ increase from its $0 \mathrm{~d}$ for the mud,

247 and it was $9 \%$ decrease from its $0 \mathrm{~d}$ for the sand.

248 Temporal changes in the Chl-b content were relatively small when compared to those in

249 the Chl-a content. However, some patterns were similar to those observed for the Chl-a content,

250

251

252

253

254

255

256

257

258

259

260

261

262

263

264

265

266

267

268

269

270

271

272

273

274

275

276

277

278

such as significantly higher for mud than for sand, and a significant effect of time $\times$ substrate interaction (Fig. 3, Table 1).

The MDA content (nmol/g) of both leaves and roots increased at the beginning of the experiment and then decreased, and it was significantly higher in leaves than in roots (Fig. 4, Table 1). The MDA content decreased visibly after $30 \mathrm{~d}$ for leaves, while it decreased steadily after $10 \mathrm{~d}$ for roots, and the effect of time $\times$ organ interaction was significant. The MDA content of leaves was higher in aquaria with mud than sand, whereas an opposite pattern was observed for roots, and the effect of organ $\times$ substrate interaction was significant. The decline in MDA content from 30 to $50 \mathrm{~d}$ was steeper for mud than for sand. Consequently, the MDA content at 50 d was $17 \%$ (leaves) or $5 \%$ (roots) decrease from its $0 \mathrm{~d}$ for the mud, and it was $8 \%$ (leaves) or $52 \%$ (roots) increase from its $0 \mathrm{~d}$ for the sand.

The SOD activity (unit/g) increased after $10 \mathrm{~d}$ in leaves, whereas it changed less throughout the experiment in roots, and the effect of time $\times$ organ interaction was significant (Fig. 4 , Table 1). As a consequence, the SOD activity in leaves exceeded that in roots from $20 \mathrm{~d}$ onwards. The SOD activity in leaves changed less after $30 \mathrm{~d}$. No significant difference was detected in the SOD activity between the two substrates.

The CAT activity $\left(\mathrm{H}_{2} \mathrm{O}_{2} \mathrm{nmol} / \mathrm{g} / \mathrm{min}\right)$ of both leaves and roots increased at the beginning of the experiment and then gradually decreased, and the effect of time was significant (Fig. 4, Table 1). The CAT activity was significantly higher in leaves than in roots throughout the experiment. No significant difference was detected in the CAT activity between the two substrates. The CAT activity at $50 \mathrm{~d}$ was $27-54 \%$ increase from its $0 \mathrm{~d}$ in leaves, and it was $5-$ $10 \%$ decrease from its $0 \mathrm{~d}$ in roots.

The POD activity $\left(A_{470} / \mathrm{g} / \mathrm{min}\right)$ of both leaves and roots increased at the beginning of the experiment and then gradually decreased, and the effect of time was significant (Fig. 4, Table 1). The POD activity was significantly higher in roots than in leaves throughout the experiment. The POD activity in roots was higher for sand than for mud throughout the experiment, whereas the difference between the two substrates remained unclear in leaves, and the effect of organ $\times$ substrate was significant. The POD activity at $50 \mathrm{~d}$ was $28-55 \%$ decrease from its $0 \mathrm{~d}$ in leaves, while it was $120-125 \%$ increase from its $0 \mathrm{~d}$ in roots.

Peer) reviewing PDF | (2020:04:48470:2:0:NEW 23 Sep 2020) 
279

280

281

282

283

284

285

286

287

288

289

290

291

292

293

294

295

296

297

298

299

300

301

302

303

304

305

306

307

308

309

310

311

312

313

314

315

316

317

318

Ramets grew well in aquaria with water and mud from the pond (Fig. 5). The leaf length $(\mathrm{cm})$ increased from $27.8 \mathrm{~cm}( \pm 2.0 \mathrm{SD}, n=3)$ before the experiment to $47.4 \mathrm{~cm}( \pm 2.9 \mathrm{SD})$ and $38.8 \mathrm{~cm}( \pm 3.6 \mathrm{SD})$ in aquaria with mud and sand, respectively, at the end of the experiment (Welch's two-sample $t$-test, $t=-2.720, d f=3.224, p=0.067$ ). The leaf number per ramet increased from $13.3( \pm 1.2 \mathrm{SD}, n=3)$ before the experiment to $45.0( \pm 2.4 \mathrm{SD}, n=3)$ and 35.7 $( \pm 4.2 \mathrm{SD}, n=3)$ in aquaria with mud and sand, respectively, at the end of the experiment (Welch's two-sample $t$-test, $t=-2.521, d f=3.124, p=0.083$ ). Thus, the growth of $V$. natans was greater for mud than for sand.

The water quality of aquaria also changed during the experiment. For example, $\mathrm{pH}$ increased from 8.3 before the experiment to 9.2 and 9.4, and DO $(\mathrm{mg} / \mathrm{L})$ increased from 2.04 to 9.11 and 10.02 in aquaria with mud and sand, respectively, at the end of experiment. Such an increase was expected as a result of plant photosynthesis, which involves consumption of $\mathrm{CO}_{2}$ and production of $\mathrm{O}_{2}$. On the other hand, the concentrations of $\mathrm{N}$ and $\mathrm{P}$ had decreased after the experiment. For example, TN (mg/L) decreased from 8.59 to $2.34( \pm 0.65 \mathrm{SD})$ and $1.83( \pm 0.52$ $\mathrm{SD})$, and TP (mg/L) decreased from 0.11 to $0.078( \pm 0.017 \mathrm{SD})$ and $0.071( \pm 0.010 \mathrm{SD})$ for mud and sand, respectively. The reduction of $\mathrm{N}$ and $\mathrm{P}$ in the water seems to be associated with nutrient uptake by $V$. natans. TN and TP were slightly higher for mud, which originally contained nutrients, than for sand.

\section{Field experiment}

The water quality of the pond varied among the sampling days (Table S1). For example, at $0.5 \mathrm{~m}$ depth, the water temperature, $\mathrm{pH}, \mathrm{DO}, \mathrm{Chl}-\mathrm{a}$ concentration, and turbidity varied from 21.7 to $25.0^{\circ} \mathrm{C}, 7.9$ to $8.3,6.4$ to $10.0 \mathrm{mg} / \mathrm{L}, 28.1$ to $62.9 \mathrm{mg} / \mathrm{L}$, and 34.8 to $75.8 \mathrm{NTU}$, respectively. In contrast, the water quality exhibited less variation among $0.5 \mathrm{~m}, 1.2 \mathrm{~m}$, and $2.0 \mathrm{~m}$ depths at each day. For example, at $0 \mathrm{~d}$, the water temperature and $\mathrm{pH}$ at all depths were $21.7^{\circ} \mathrm{C}$ and 8.2 , respectively, DO, Chl-a concentration, and turbidity varied from 9.9 to $10.0 \mathrm{mg} / \mathrm{L}, 62.9$ to 70.4 $\mathrm{mg} / \mathrm{L}$, and 44.9 to 48.6 NTU, respectively. Similarly, the COD (range: $24-77 \mathrm{mg} / \mathrm{L}$ ), TN (5.63$9.65 \mathrm{mg} / \mathrm{L})$, TP $(0.36-0.64 \mathrm{mg} / \mathrm{L})$ varied among days, but they exhibited less variation among the three depths at each day.

The light quantum ( $\left.\mu \mathrm{mol} / \mathrm{m}^{2} \mathrm{~s}\right)$ at each depth also exhibited temporal variation (Fig. 6). In addition, it decreased with increasing depth every day, declining to almost half and less than onetenth from the depth of $0.5 \mathrm{~m}$ (mean: $\left.79.3 \mu \mathrm{mol} / \mathrm{m}^{2} \mathrm{~s}\right)$ to $1.2 \mathrm{~m}\left(38.3 \mu \mathrm{mol} / \mathrm{m}^{2} \mathrm{~s}\right)$ and $2.0 \mathrm{~m}$ $\left(6.7 \mu \mathrm{mol} / \mathrm{m}^{2} \mathrm{~s}\right)$, respectively. Water transparency gradually increased from 0.25 to $0.30 \mathrm{~m}$ during the experiment (Table S1). Rainy days were more frequent in the latter half of the experiment, with a maximum daily rainfall of $42.2 \mathrm{~mm}$ and total rainfall of $208 \mathrm{~mm}$ during the experiment (Fig. S1).

The leaf Chl-a content $(\mathrm{mg} / \mathrm{g})$ declined sharply at the beginning of the experiment, particularly at the depths of 1.2 and $2.0 \mathrm{~m}$ (Fig. 7). The change in Chl-a content after $10 \mathrm{~d}$ differed depending on the water depth, and the effects of time and time $\times$ depth interaction were significant (Fig. 7, Table 2). After $10 \mathrm{~d}$, the Chl-a content increased slightly at the depth of 0.5 
$319 \mathrm{~m}$, whereas it declined steadily at 1.2 and $2.0 \mathrm{~m}$. The Chl-a content decreased with increasing 320 depth, and the effect of depth was significant. However, no clear difference was observed

321

322

323

324

325

326

327

328

329

330

331

332

333

334

335

336

337

338

339

340

341

342

343

344

345

346

347

348

349

350

351

352

353

354

355

356

357

358

between mud and sand. The Chl-b content also decreased with increasing depth, and the difference between mud and sand remained unclear (Fig. 7, Table 2).

The MDA content (nmol/g) of leaves increased 2- to 3-fold during the experiment, whereas the content of roots changed less, and the effects of time and time $\times$ organ interaction were significant. The MDA content was significantly higher in leaves than in roots throughout the experiment (Fig. 8, Table 2). The MDA content was also significantly higher in deeper positions, and significantly higher for sand than for mud. Consequently, the MDA content of leaves and roots at $30 \mathrm{~d}$ was the lowest for mud at $0.5 \mathrm{~m}$.

The SOD activity (unit/g) of leaves and roots increased at the beginning of the experiment at all depths. However, the change of the SOD activity in the latter half of the experiment differed depending on the depth (Fig. 8, Table 2); during this period the SOD activity at 0.5 and $1.2 \mathrm{~m}$ increased continuously but slowly, whereas that at $2.0 \mathrm{~m}$ decreased, and the effects of time and time $\times$ depth interaction were significant. At 0.5 and $1.2 \mathrm{~m}$, the SOD activity increased 3- to 4-fold and 2- to 3-fold during the experiment in leaves and in roots, respectively, and the effects of organ, time $\times$ organ interaction, and organ $\times$ depth interaction were significant. In addition, the SOD activity was significantly higher for mud than for sand, particularly in roots at 0.5 and $1.2 \mathrm{~m}$ depths, and the effects of substrate and time $\times$ substrate, organ $\times$ substrate, and depth $\times$ substrate interactions were significant.

The CAT activity $\left(\mathrm{H}_{2} \mathrm{O}_{2} \mathrm{nmol} / \mathrm{g} / \mathrm{min}\right)$ of leaves and roots increased at the beginning of the experiment at all depths. However, the change of the SOD activity in the latter half of the experiment differed depending on the depth (Fig. 8, Table 2); during this period, the CAT activity at 0.5 and $1.2 \mathrm{~m}$ increased continuously but slowly, whereas that at $2.0 \mathrm{~m}$ decreased. This pattern was similar to that of the SOD activity. The difference in the CAT activity between leaves and roots remained unclear. The CAT activity was significantly higher for sand than for mud.

The POD activity $\left(A_{470} / \mathrm{g} / \mathrm{min}\right)$ of leaves and roots increased slightly at 0.5 and $1.2 \mathrm{~m}$ during the experiment, whereas it increased sharply at the beginning of the experiment and then decreased at $2.0 \mathrm{~m}$ depth, and the effects of time and time $\times$ depth interaction were significant (Fig. 8, Table 2). The POD activity was significantly higher in leaves than in roots, whereas no significant difference was observed between mud and sand.

The ramets of $V$. natans did not exhibit an apparent increase in the length and number of leaves during the experiment (Fig. 9); they rather decreased at $1.2 \mathrm{~m}$ and $2.0 \mathrm{~m}$ depths. The length and number of leaves tended to decrease with increasing water depth, and were less for sand than for mud, but due to a variation among trays a significant effect was detected only for depth and depth $\times$ substrate interaction on leaf number (depth: $d f=2, F=24.4, p<0.001$; substrate: $d f=1, F=3.56, p=0.071$; depth $\times$ substrate: $d f=2, F=5.06, p=0.015)$. The leaves of ramets at $0.5 \mathrm{~m}$ were completely green, but some leaf apices were flat (i.e., not acute like before the experiment), resembling being cut by animals in the pond (e.g., fish, birds). The leaves of

Peer) reviewing PDF | (2020:04:48470:2:0:NEW 23 Sep 2020) 
359

360

361

362

363

364

365

366

367

368

369

370

371

372

373

374

375

376

377

378

379

380

381

382

383

384

385

386

387

388

389

390

391

392

393

394

395

396

397

398

ramets at $1.2 \mathrm{~m}$ were only partially green, and the leaves at $2.0 \mathrm{~m}$ were light brown, indicating senescence.

\section{Discussion}

In the present study, we examined the growth and physiological status of $V$. natans under the water and mud conditions of an urban pond using laboratory and field experiments. Plant physiological status was assessed using photosynthetic pigments, Chl-a and Chl-b, as plant health indicators, and a lipid peroxidation product, i.e., MDA, and antioxidant enzymes, including SOD, CAT, and POD, as stress indicators. Ramets grew well in the laboratory and physiological status differed less between 0 and $50 \mathrm{~d}$ of the experiment in both mud and sand. Thus, the water of the pond, which is more or less polluted due to urban human activities, is unlikely to directly or adversely affect $V$. natans. High $\mathrm{N}$ and $\mathrm{P}$ concentrations can have toxic effects on $V$. natans (Cao et al. 2007, Wang et al. 2008). However, N and P concentrations in water decreased during our laboratory experiment, which is likely to be associated with nutrient uptake and growth of $V$. natans. We also revealed that the growth and physiological status of $V$. natans were better with mud than with sand as a substrate. Thus, although the mud of the pond was rich in organics, an adverse effect of such mud on submerged plants (Barko and Smart 1986, Wu et al. 2009, Silveila and Thomaz 2015) was not evident in this study. We used sand, which was free of organic matter, as the control substrate. Substrate type and nutrient contents are considered to be important for the nutrient acquisition by the roots of $V$. natans (Xie et al. 2005, Xiao et al. 2007, Bai et al. 2015). Although high $\mathrm{N}$ and $\mathrm{P}$ concentrations in water possibly compensate for a low nutrient content in substrate, sand may be less suitable than natural mud or clay for roots to adjust and acquire nutrients. Further studies using different substrates, such as mud in oligotrophic lakes, are required to examine the suitability of the mud from eutrophic ponds for transplanting $V$. natans.

The adverse effects of water depth and reduced light availability on $V$. natans were evident in the field experiment. The leaf number of ramets decreased with increasing depth at the end of the experiment. Moreover, the Chl-a and Chl-b contents of leaves decreased, and the MDA content of leaves and roots increased with increasing water depth. Interestingly, the activities of antioxidant enzymes, SOD, CAT, and POD, increased at the beginning of the experiment and then decreased at $2.0 \mathrm{~m}$ depth. This was likely due to the oxidative damage caused by excessive production of ROS under low-light conditions at this depth. Such a deterioration of enzyme activity has been reported for $V$. natans exposed to lead (Yan et al. 2006, Wang et al. 2012). Light availability is the important factor that varies vertically in the study pond. A sharp decline in light availability with increasing depth was detected in this study; the light quantum was reduced by $50 \%$ and $90 \%$ from $0.5 \mathrm{~m}$ to 1.2 and $2.0 \mathrm{~m}$, respectively. Bai et al. (2015) also reported a $62 \%$ and $99 \%$ reduction in the light quantum from the surface to 0.6 and $1.8 \mathrm{~m}$ in an experimental pond, respectively. Such a sharp attenuation in light availability is typical of eutrophic ponds and lakes (Hodoki and Watanabe 1998, De Lange 2000). On the other hand, only small differences were detected in the vertical profile of water quality, including 
399

400

401

402

403

404

405

406

407

408

409

410

411

412

413

414

415

416

417

418

419

420

421

422

423

424

425

426

427

428

429

430

431

432

433

434

435

436

437

438

temperature, DO, and $\mathrm{N}$ and $\mathrm{P}$ concentrations, in this pond. These results suggest that $V$. natans experiences strong stress at greater depths in this pond due to light depletion, which impedes photosynthesis. Most area inside the study pond was near or greater than $2.0 \mathrm{~m}$ deep, at which the growth of $V$. natans is likely to be inhibited.

Light availability, which is regulated by water depth and transparency, has been identified as the main factor limiting the distribution of submerged plants including $V$. natans (Voesenek et al. 2006, Bai et al. 2015, Dong et al. 2014, Han and Cui 2016). The optimal water depth for the growth of $V$. natans has been reported as 100-160 cm in an oligotrophic lake (Xiao et al. 2017), in which water transparency and light availability were high. However, a steep light attenuation with increasing depth in eutrophic lakes and ponds is likely to limit the distribution of $V$. natans to shallow areas. Han and Cui (2016) used the ratio of transparency to water depth as an indicator of eutrophication pressure on macrophyte communities. They suggested that the ratio should be no less than 0.52 to restore submerged species in eutrophic ponds. Based on this criterion, and because the maximum transparency in our study pond was $0.3 \mathrm{~m}$, shallow area less than $0.58 \mathrm{~m}$ deep are required to restore submerged plants. Although a deterioration of enzyme activity was not observed at 0.5 and $1.2 \mathrm{~m}$ in this study, $V$. natans is unlikely to be able to tolerate low light stress for a long period. Less growth, reduced Chl contents, and increased level of stress indicators of $V$. natans even at $0.5 \mathrm{~m}$ in this study may suggest that $0.5 \mathrm{~m}$ or shallower areas are required for the growth of this plant in this pond. However, too shallow area may be unsuitable for $V$. natans, which is originally adapted to habitats deeper than $1 \mathrm{~m}$ (Xiao et al. 2007, Li et al. 2020), to grow vertically well in the water column. Because we examined limited depths deeper than $0.5 \mathrm{~m}$ in the field, further studies are needed to clarify the suitability of such shallow areas for the growth and survival of $V$. natans in eutrophic ponds.

The strong effect of depth on $V$. natans might have obscured the differences between mud and sand in the field experiment. Differences in growth and leaf Chl-a and Chl-b contents between mud and sand, which were observed in the laboratory experiment, were not detected in the field experiment. The MDA content and CAT activity of leaves and roots were higher for sand than for mud in the field, which were not detected in the laboratory experiment. Although there are different results between the experiments, the results of field study suggest that the mud of the pond is unlikely to be a limiting factor in the establishment of $V$. natans.

Sufficient light and low nutrient concentrations in water were more advantageous to the ramets in the laboratory than to those in the field. The growth and physiological status of leaves and roots were obviously better in the laboratory than in the field, evident from the increase in length and number of leaves, lesser decrease in the Chl-a and Chl-b contents, and lesser increase in the MDA content and antioxidant enzyme activities. The MDA content and activities of antioxidant enzymes, except SOD, declined after a small increase in the early stages of the laboratory experiment. The decline of these indices to the initial or even smaller values at the end of the experiment may indicate ramets acclimatization to the aquaria environment. The mean light quantum at $0.5 \mathrm{~m}$ depth $\left(79.3 \mu \mathrm{mol} / \mathrm{m}^{2} \mathrm{~s}\right)$ was similar to the intensity of light in the incubator $\left(70-80 \mu \mathrm{mol} / \mathrm{m}^{2} \mathrm{~s}\right)$. However, the light quantum would be smaller inside the meshed 
439 cages used to grow ramets in the field. Although the nutrient concentration was initially similar 440 between the aquaria and pond, nutrient uptake by ramets substantially reduced the nutrient 441 concentration in the aquaria at the end of the experiment. High nutrient concentrations can 442 adversely affect $V$. natans, both directly and indirectly, by promoting epiphytic algal growth on $443 V$. natans (Song et al. 2015). Ramets in the field were also at a risk of grazing by animals such as 444 birds and fish. Some leaf apices of $V$. natans were flat, likely to have been eaten partially by

445

446

447

448

449

450

451

452

453

454

455

456

457

458

459

460

461

462

463

464

465

466

467

468

469

470

471

472

473

474

475

476

477

478 pond animals. This was supported by a chance observation of a fish feeding on $V$. natans collected in a bucket (personal observation). The better growth and physiological status of ramets in the laboratory than in the field may be partially associated with the absence of predator and hydrologic disturbance in the former. Present study is inadequate to show the importance of water depth and light on $V$. natans across different seasons and life stages, and how physical disturbances can modify the depth related responses of $V$. natans.

Previous studies have shown increased MDA content in $V$. natans growing under salinity, lead, and ammonia stress (Wang et al. 2008, Hao et al. 2011, Li et al. 2011, Song et al. 2015). In our study, the MDA content was higher with increasing depth. The accumulation of MDA eventually inactivates the enzymes associated with photosynthesis, respiration, and other metabolic processes in plant cells (Song et al. 2015). Of the three enzymes analyzed in this study, SOD showed the strongest response, in terms of the magnitude of changes in both laboratory and field experiments. SOD converts $\mathrm{O}_{2}{ }^{-}$into $\mathrm{O}_{2}$ and $\mathrm{H}_{2} \mathrm{O}_{2}$ in the first step of ROS removal (Apel and Hirt 2004, Rahnama and Ebrahimzadeh 2005). On the other hand, POD exhibited the fastest response (i.e., stopped increasing the earliest) among the enzymes in both laboratory and field experiments. Both POD and CAT convert $\mathrm{H}_{2} \mathrm{O}_{2}$ into $\mathrm{H}_{2} \mathrm{O}$ and $\mathrm{O}_{2}$ (Bowler et al. 1992). Responses of these enzymes varied depending on the study (Yan et al. 2006, Hao et al. 2011, Li et al. 2011, Wang et al. 2012), and further studies are required to generalize the response of each enzyme.

\section{Conclusions}

We demonstrated important factors on the growth and physiological status of $V$. natans in eutrophic urban ponds using laboratory and field experiments. Sufficient light availability is required for better physiological status of the species. Owing to the sharp attenuation of light with increasing depth, shallow areas less than $1 \mathrm{~m}$ deep and improved water transparency are fundamental requirements for successful re-introduction of $V$. natans in eutrophic ponds. Despite the anaerobic conditions prevailing in the mud at the pond bottom, no adverse effects were detected on $V$. natans in the present study. Thus, it is suggested that the current status of the bottom mud does not directly inhibit the growth of submerged species. However, it can indirectly affect growth by releasing nutrients in the water column, which, in turn, can induce algal blooms. Efforts to reduce the nutrient load are also important to limit the phytoplankton overgrowth, and thus, to maintain transparency and ensure light availability to submerged plants.

\section{Acknowledgements}


479 We thank the employees of the Wenzhou Science and Technology Bureau and Wenzhou Park

480 Management Office for granting permission to conduct research in the park, and providing 481 valuable information and support throughout the field study. We also thank the students of 482 Aquatic Ecology and Symbiology, College of Life and Environmental Sciences, Wenzhou 483 University, China, for helping with the laboratory and field surveys. The manuscript has been 484 greatly improved by two reviewers. Finally, we would like to thank Editage (www.editage.com) 485 for English language editing.

486

487

488

489

490

491

492

493

494

495

496

497

498

499

500

501

502

503

504

505

506

507

508

509

510

511

512

513

514

515

516

\section{References}

Apel K, Hirt H. 2004. Reactive oxygen species: metabolism, oxidative stress, and signal transduction. Annual Review of Plant Biology 55:373-399. DOI

10.1146/annurev.arplant.55.031903.141701

Arnon DI. 1949. Copper enzymes in isolated chloroplasts. Polyphenoloxidase in Beta vulgaris. Plant physiology 24(1):1-15 DOI 10.1104/pp.24.1.1

Bai X, Chen K, Zhao H, Chen X. 2015. Impact of water depth and sediment type on root morphology of the submerged plant Vallisneria natans, Journal of Freshwater Ecology 30(1):7584 DOI 10.1080/02705060.2014.970672

Barko JW, Smart RM. 1986. Sediment-related mechanisms of growth limitation in submersed macrophytes. Ecology 67(5):1328-1340 DOI 10.2307/1938689

Beauchamp C, Fridovich I. 1971. Superoxide dismutase: improved assays and an assay applicable to acrylamide gels. Analytical biochemistry 44(1):276-287 DOI 10.1016/00032697(71)90370-8.

Bowler C, Montagu MV, Inzé D. 1992. Superoxide dismutase and stress tolerance. Annual Review of Plant Physiology and Plant Molecular Biology 43:83-116.

Cao T, Xie P, Ni L, Wu A, Zhang M, Wu S, Smolders AJP. 2007. The role of NH4+ toxicity in the decline of the submersed macrophyte Vallisneria natans in lakes of the Yangtze River basin, China. Marine and freshwater research 58(6):581-587 DOI 10.1071/MF06090.

De Lange HJ. 2000. The attenuation of ultraviolet and visible radiation in Dutch inland waters. Aquatic Ecology, 34(3):215-226 DOI 10.1023/A:1009943211779.

Ellawala C, Asaeda T, Kawamura K. 2013. Water movement induced variations in growth regulation and metabolism of freshwater macrophyte Vallisneria spiralis L. in early growth stages. Hydrobiologia 709:173-182 DOI 10.1007/s10750-013-1447-3

Greenfield RE, Price VE. 1954. Liver catalase I. A manometric determination of catalase activity. Journal of Biological Chemistry 209:355-361.

Grimm NB, Faeth SH, Golubiewski NE, Redman CL, Wu J, Bai X, Briggs JM. 2008. Global change and the ecology of cities. Science 319(5864):756-760 DOI 10.1126/science.1150195.

Han Z, Cui B. 2016. Performance of macrophyte indicators to eutrophication pressure in ponds. Ecological Engineering 96:8-19 DOI 10.1016/j.ecoleng.2015.10.019. 
517 Hao A, Kuba T, Iseri Y, Zhang Z, Liu Y, Haraguchi T. 2011. Effects of copper ion on 518 antioxidant function of Vallisneria asiatica. Ecology and Civil Engineering 14(2):115-122 DOI 519 10.3825/ece.14.115 (in Japanese with English abstract).

520 Harper DM. 1992. Eutrophication of freshwaters: principles, problems and restoration. London:

521 Chapman and Hall.

522 Heath RL, Packer L. 1968. Photoperoxidation in isolated chloroplasts: I. Kinetics and 523 stoichiometry of fatty acid peroxidation. Archives of biochemistry and biophysics 125(1):189524198 DOI 10.1016/0003-9861(68)90654-1.

525 Hilt S, Gross EM, Hupfer M, Morscheid H, Mählmann J, Melzer A, Poltz J, Sandrock S, 526 Scharf E-M, Schneider S, van de Weyer K. 2006. Restoration of submerged vegetation in 527 shallow eutrophic lakes-A guideline and state of the art in Germany. Limnologica 36(3):155528 171 DOI 10.1016/j.limno.2006.06.001.

529 Hodoki Y, Watanabe Y. 1998. Attenuation of solar ultraviolet radiation in eutrophic freshwater 530 lakes and ponds. Japanese Journal of Limnology 59(1):27-37 DOI 10.3739/rikusui.59.27.

531 Ke X, Li W. 2006. Germination requirement of Vallisneria natans seeds: implications for 532 restoration in Chinese lakes. Hydrobiologia 559:357-362 DOI 10.1007/s10750-005-1276-0

533 Kochba J, Lavee S, Spiegel-Roy P. 1977. Differences in peroxidase activity and isoenzymes in 534 embryogenic ane non-embryogenic 'Shamouti'orange ovular callus lines. Plant and Cell 535 Physiology, 18(2), 463-467 DOI 10.1093/oxfordjournals.pcp.a075455.

536 Li F, Xie Y, Chen X, Pan Y, Deng Z, Li X. 2011. Plant distribution can be reflected by 537 physiological responses to salinity of three submerged macrophytes from the Modern Yellow 538 River Delta. Fundamental and Applied Limnology 179(3):159-167 DOI 10.1127/1863539 9135/2011/0179-0159.

540 Li H, Li Q, Luo X, Fu J, Zhang J. 2020. Responses of the submerged macrophyte Vallisneria 541 natans to a water depth gradient. Science of the Total Environment 701:134944 DOI

542 10.1016/j.scitotenv.2019.134944.

543 Li JC, Maezawa S, Nakano K. 2002. Determination of superoxide by nitrite ion method.

544 Horticultural research (Japan) 1(4):279-282 (in Japanese with English abstract) DOI 545 10.2503/hrj.1.279.

546 Li ZQ, Kong LY, Yang LF, Zhang M, Cao T, Xu J, Wang ZX, Lei Y. 2012. Effect of 547 substrate grain size on the growth and morphology of the submersed macrophyte Vallisneria 548 natans L. Limnologica 42(1):81-85 DOI 10.1016/j.limno.2011.09.003.

549 Lowden RM. 1982. An approach to the taxonomy of Vallisneria L. (Hydrocharitaceae). Aquatic 550 Botany 13:269-298 DOI 10.1016/0304-3770(82)90064-X.

551 Madsen JD, Chambers PA, James WF, Koch EW, Westlake DF. 2001. The interaction

552 between water movement, sediment dynamics and submerged macrophytes. Hydrobiologia 553 444:71-84 DOI 10.1023/A:1017520800568.

554 Qin BQ, Gao G, Zhu GW, Zhang YL, Song YZ, Tang XM, Xu H, Deng JM. 2013. Lake 555 eutrophication and its ecosystem response. Chinese Science Bulletin 58:961-970 DOI 556 10.1007/s11434-012-5560-x. 
557 Qiu D, Wu ZB, Liu BY, Deng JQ, Fu GP, He F. 2001. The restoration of aquatic macrophytes 558 for improving water quality in a hypertrophic shallow lake in Hubei Province, China. Ecological 559 Engineering 18(2):147-156 DOI 10.1016/S0925-8574(01)00074-X.

560 Rahnama H, Ebrahimzadeh H. 2005. The effect of $\mathrm{NaCl}$ on antioxidant enzyme activities in 561 potato seedlings. Biologia Plantarum 49: 93-97 DOI 10.1007/s10535-005-3097-4.

562 Sayer CD, Burgess AMY, Kari K, Davidson TA, Peglar S, Yang H, Rose N. 2010. Long-

563 term dynamics of submerged macrophytes and algae in a small and shallow, eutrophic lake:

564 implications for the stability of macrophyte-dominance. Freshwater Biology 55(3):565-583 DOI 565 10.1111/j.1365-2427.2009.02353.x.

566 Silveira MJ, Thomaz SM. 2015. Growth of a native versus an invasive submerged aquatic 567 macrophyte differs in relation to mud and organic matter concentrations in sediment. Aquatic

568 Botany 124:85-91 DOI 10.1016/j.aquabot.2015.03.004

569 Smith VH, Schindler DW. 2009. Eutrophication science: where do we go from here? Trends in 570 Ecology \& Evolution 24(4):201-207 DOI10.1016/j.tree.2008.11.009.

571 Song Y-Z, Kong F-F, Xue Y, Qin B-Q. 2015. Responses of chlorophyll and MDA of

572 Vallisneria natans to nitrogen and phosphorus availability and epiphytic algae. Journal of

573 Freshwater Ecology 30(1):85-97 DOI 10.1080/02705060.2014.989554

574 State Environmental Protection Administration. 2002. Surface Water Environment Quality

575 Standard (GB 3838-2002), China Environmental Science Press, Beijing

576 Voesenek LACJ, Colmer TD, Pierik R, Millenaar FF, Peeters AJM. 2006. How plants cope

577 with complete submergence. New Phytologist 170(2):213-226 DOI 10.1111/j.1469-

578 8137.2006.01692.x.

579 Wang C, Zhang SH, Wang PF, Hou J, Li W, Zhang WJ. 2008. Metabolic adaptations to 580 ammonia-induced oxidative stress in leaves of the submerged macrophyte Vallisneria natans 581 (Lour.) Hara. Aquatic Toxicology 87(2):88-98 DOI 10.1016/j.aquatox.2008.01.009.

582 Wang J, Chen G, Liu F, Song X, Zou G. 2017. Combined ozonation and aquatic macrophyte

583 (Vallisneria natans) treatment of piggery effluent: Water matrix and antioxidant responses.

584 Ecological engineering 102:39-45 DOI 10.1016/j.ecoleng.2017.01.033.

585 Wang $\mathbf{P}$, Zhang $\mathrm{S}$, Wang $\mathbf{C}$, Lu J. 2012. Effects of $\mathrm{Pb}$ on the oxidative stress and antioxidant 586 response in a $\mathrm{Pb}$ bioaccumulator plant Vallisneria natans. Ecotoxicology and environmental 587 safety 78:28-34 DOI 10.1016/j.ecoenv.2011.11.008.

588 Wu J, Cheng S, Liang W, Wu Z. 2009. Effects of organic-rich sediment and below-ground 589 sulfide exposure on submerged macrophyte: Hydrilla verticillata. Bulletin of Environmental 590 Contamination and Toxicology 83:497-501 DOI 10.1007/s00128-009-9800-y

591 Xian Q, Chen H, Liu H, Zou H, Yin D. 2006. Isolation and identification of antialgal

592 compounds from the leaves of Vallisneria spiralis L. by activity-guided fractionation.

593 Environmental Science and Pollution Research 13:233-237 DOI 10.1065/espr2006.06.314

594 Xiao KY, Yu D, Wu ZH. 2007. Differential effects of water depth and sediment type on clonal 595 growth of the submerged macrophyte Vallisneria natans. Hydrobiologia 589:265-27 DOI

596 10.1007/s10750-007-0740-4 2. 
597 Xie Y, An S, Wu B. 2005. Resource allocation in the submerged plant Vallisneria natans related

598 to sediment type, rather than water - column nutrients. Freshwater Biology 50(3):391-402 DOI

599 10.1111/j.1365-2427.2004.01327.x.

600 Xing X, Ding S, Liu L, Chen M, Yan W, Zhao L, Zhang C. 2018. Direct evidence for the

601 enhanced acquisition of phosphorus in the rhizosphere of aquatic plants: a case study on

602 Vallisneria natans. Science of the Total Environment 616-617:386-396 DOI

603 10.1016/j.scitotenv.2017.10.304.

604 Xiong BH, Li W. 2000. Ecological studies on Vallisneria L. in China. Journal of Wuhan

605 Botanical Research 18:500-508 (in Chinese with English abstract).

606 Xiong BH, Hou HB, Zhong Y. 2005. The Effect of water depth on seedling emergence and

607 early growth of Vallisneria natans in a eutrophic lake with reduced transparency. Journal of

608 Freshwater Ecology 20(1):123-127 DOI 10.1080/02705060.2005.9664945.

609 Xu W, Hu W, Deng J, Zhu J, Zhou N, Liu X. 2016. Impacts of water depth and substrate type 610 on Vallisneria natans at wave-exposed and sheltered sites in a eutrophic large lake. Ecological 611 Engineering 97:344-354 DOI 10.1016/j.ecoleng.2016.10.029.

612 Yan GA, Ren N, Ma JM, Qiu DY, Wu ZB. 1997. Success and species replacement of aquatic 613 plant community in East Lake. Acta Phytoecologica Sinca 21:319-327.

614 Yan X, Yu D, Wang H, Wang J. 2006. Response of submerged plant (Vallisneria spinulosa)

615 clones to lead stress in the heterogenous soil. Chemosphere 63(9):1459-1465 DOI

616 10.1016/j.chemosphere.2005.09.030. 
Figure 1

Location (A), map (B), and view (C) of the study site

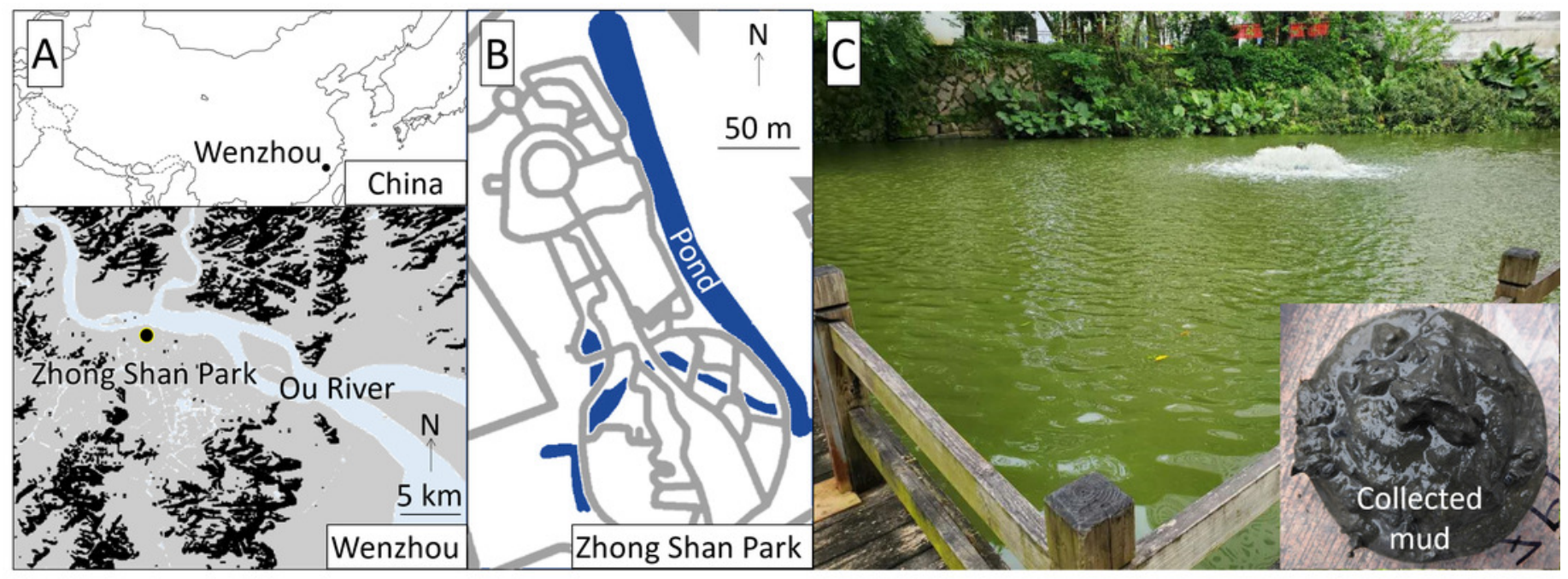




\section{Figure 2}

Schematic view of the field experimental design $(A)$ and arrangement of ramets in a cage (B)
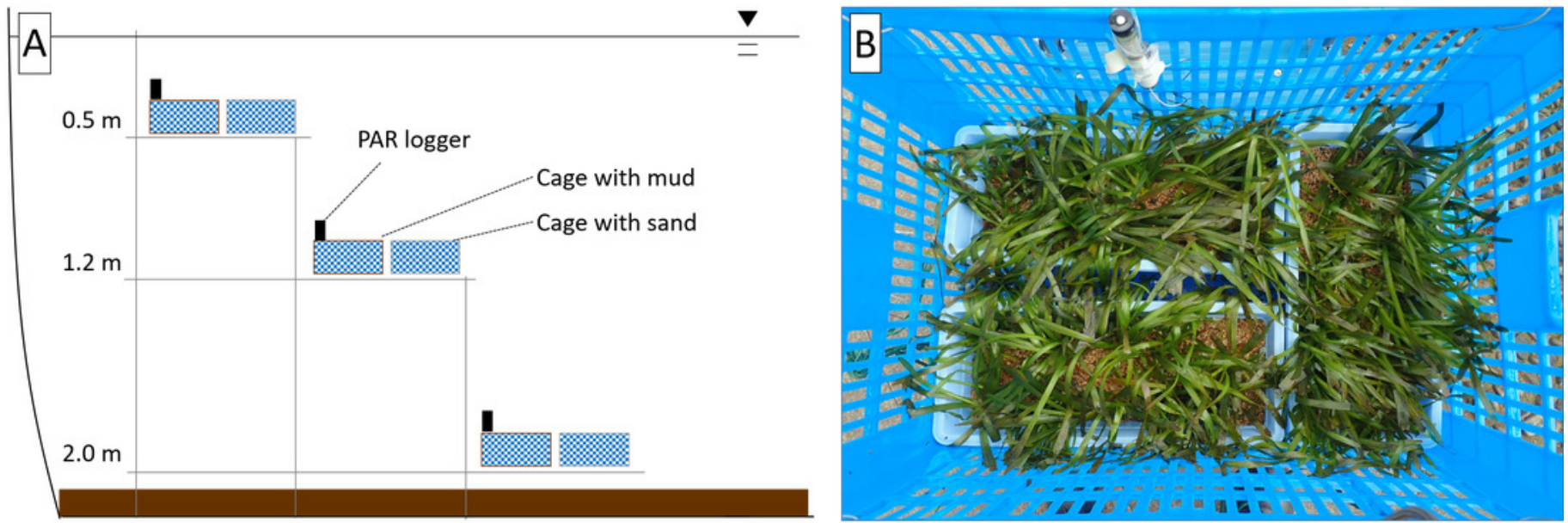
Figure 3

Changes in the chlorophyll content of leaves in the laboratory experiment

Error bars denote $1 \mathrm{SD}(n=3)$. Factors with significant effect on Chl-a and Chl-b are shown right (***: $p<0.001, * *: p<0.01, *: p<0.05)$. Data of day 0 and 5 were not used in the statistical analysis. 


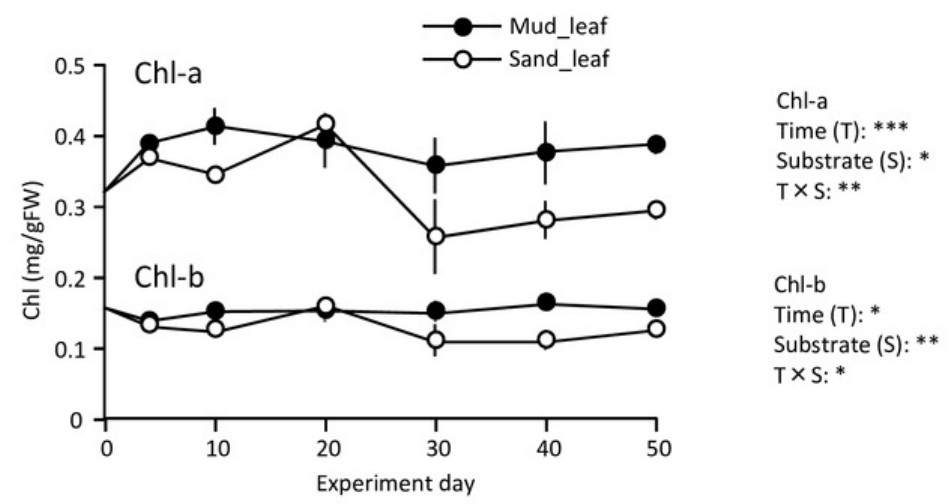


Figure 4

Changes in lipid peroxidation product (MDA) (A) and enzyme (SOD, CAT, and POD) activity $(B, C$, and $D)$ of leaves and roots in the laboratory experiment

Error bars denote $1 \mathrm{SD}(n=3)$. Factors with significant effect on MDA, SOD, CAT, and POD are shown right $(* * *: p<0.001, * *: p<0.01, *: p<0.05)$. Data of day 0 and 5 were not used in the statistical analysis. 


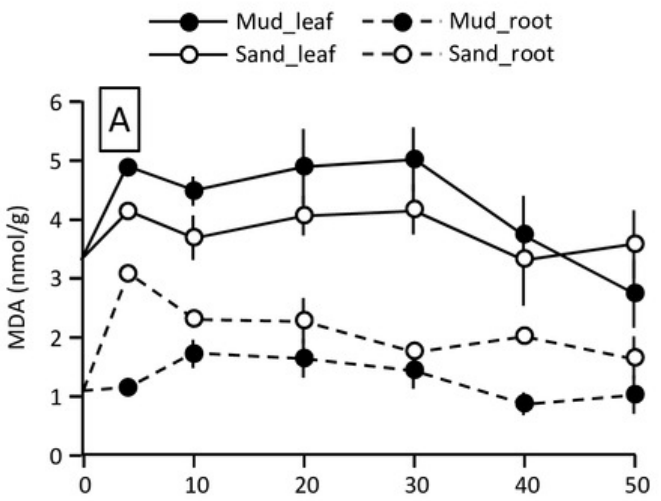

MDA

Time (T): ***

Organ (O): ***

$\mathrm{T} \times \mathrm{O}:{ }^{*}$

$\mathrm{T} \times \mathrm{S}: *$

$\mathrm{O} \times \mathrm{S}: * * *$

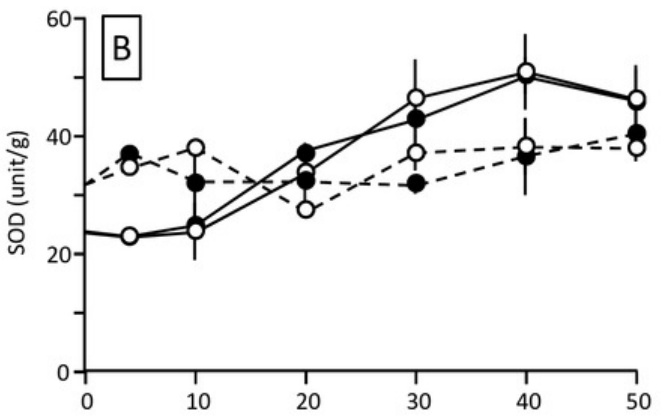

SOD

Time $(\mathrm{T}): * * *$

Organ (O): ***

$\mathrm{T} \times \mathrm{O}: * * *$

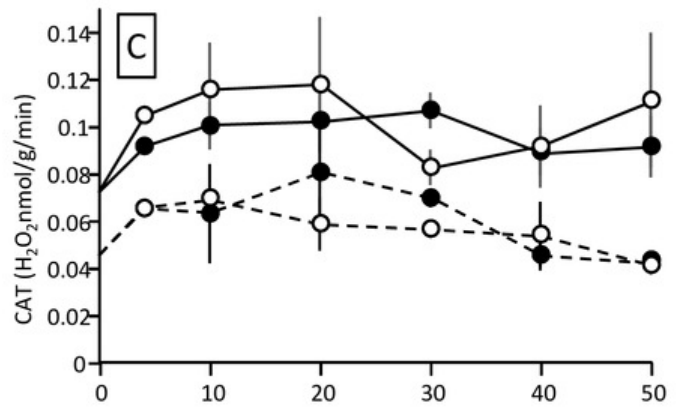

CAT

Time (T): **

Organ (O): ***

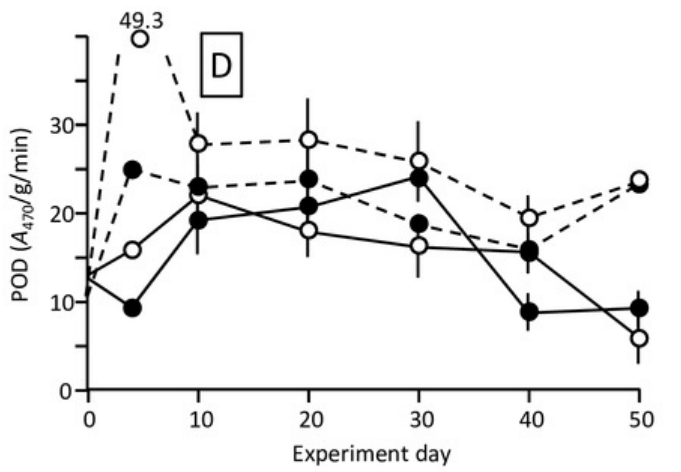

POD

Time (T): ***

Organ (O): ***

$\mathrm{T} \times \mathrm{O}: * * *$

$\mathrm{T} \times \mathrm{S}: *$

$\mathrm{O} \times \mathrm{S}: * *$

$\mathrm{T} \times \mathrm{O} \times \mathrm{S}: * *$ 
Figure 5

Length (bar) and number (circle) of leaves before and at the end of the laboratory experiment

Error bars denote $1 \mathrm{SD}(n=3)$. 


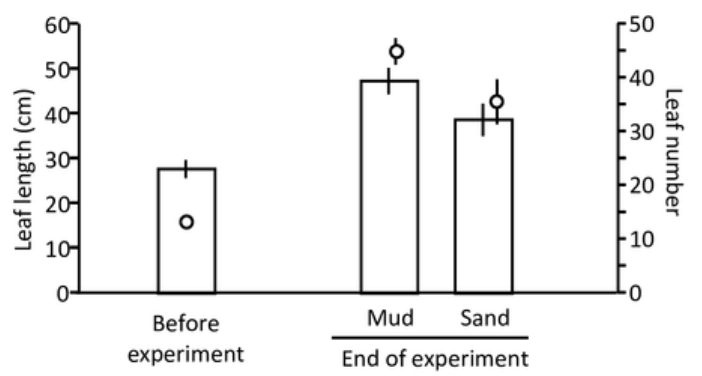


Figure 6

Light quantum $\left(\mu \mathrm{mol} / \mathrm{m}^{2} \mathrm{~s}\right)$ at different depths in the pond during the field experiment 


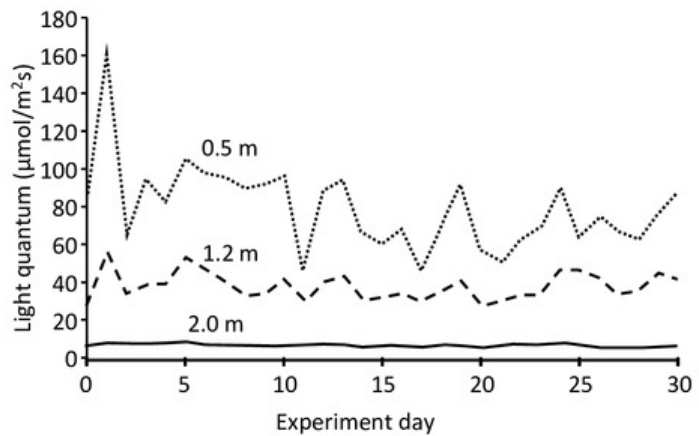


Figure 7

Changes in Chl-a (A) and Chl-b (B) contents of leaves during the field experiment

Error bars denote $1 \mathrm{SD}(n=3)$. Factors with significant effect on Chl-a and Chl-b are shown right (***: $p<0.001, * *: p<0.01, *: p<0.05)$. Data of day 0 were not used in the statistical analysis. 
- - Mud_0.5 m $\cdots . . \cdots \cdots$ Sand_0.5 m

- - Mud_1.2 m $\cdots . . \cdot \cdots \cdot$ Sand_1.2 m

$\longrightarrow$ Mud_2.0 m $\cdots . \cdots$ Sand_2.0 m

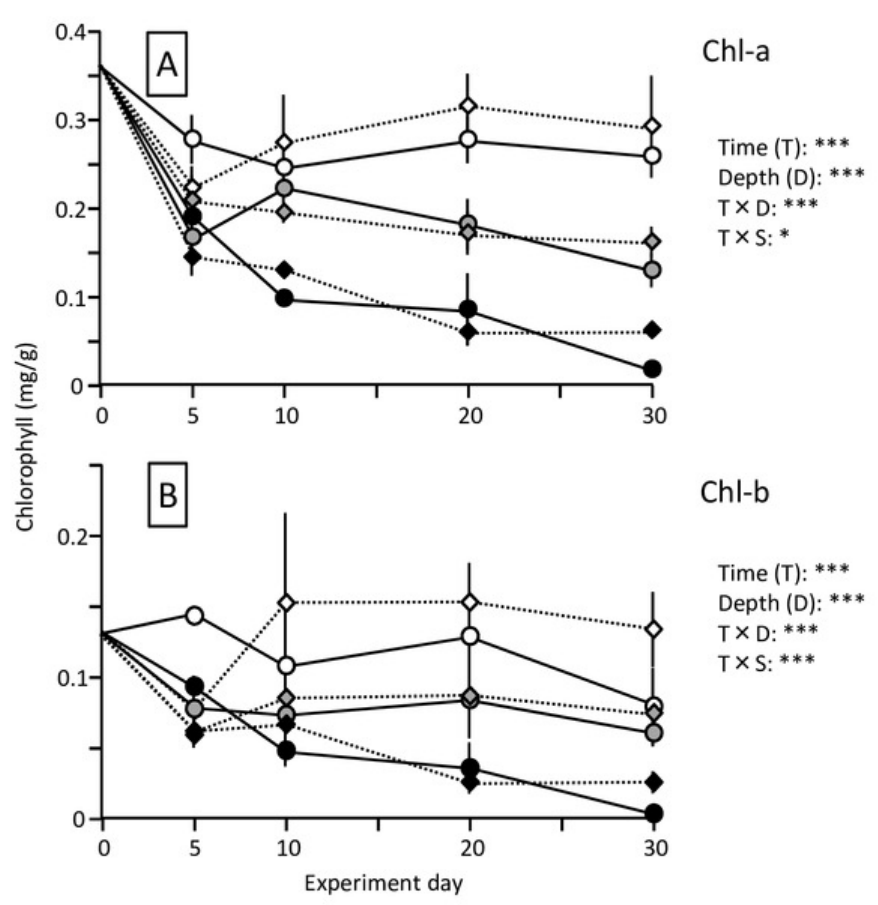


Figure 8

Changes in lipid peroxidation product (MDA) and enzyme (SOD, CAT, and POD) activity of leaves (A-D) and roots $(E-H)$ in the field experiment

Error bars denote $1 \mathrm{SD}(n=3)$. Factors with significant effect on MDA, SOD, CAT, and POD are shown right $(* * *: p<0.001, * *: p<0.01, *: p<0.05,+: p<0.1)$. Data of day 0 were not used in the statistical analysis. 


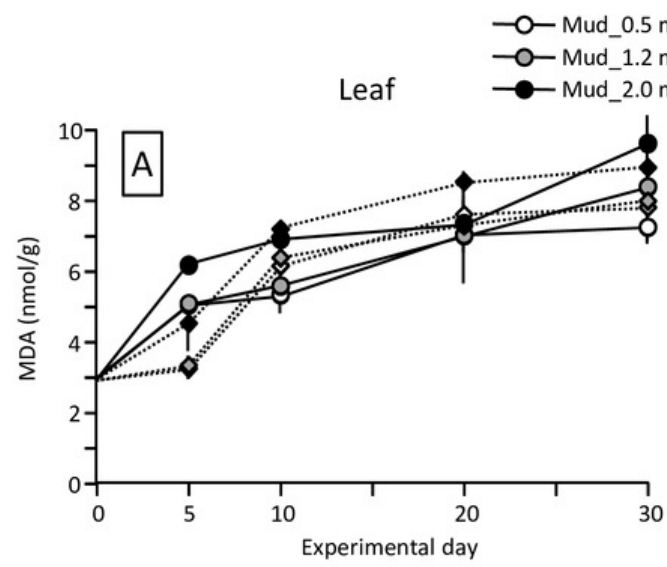

Root
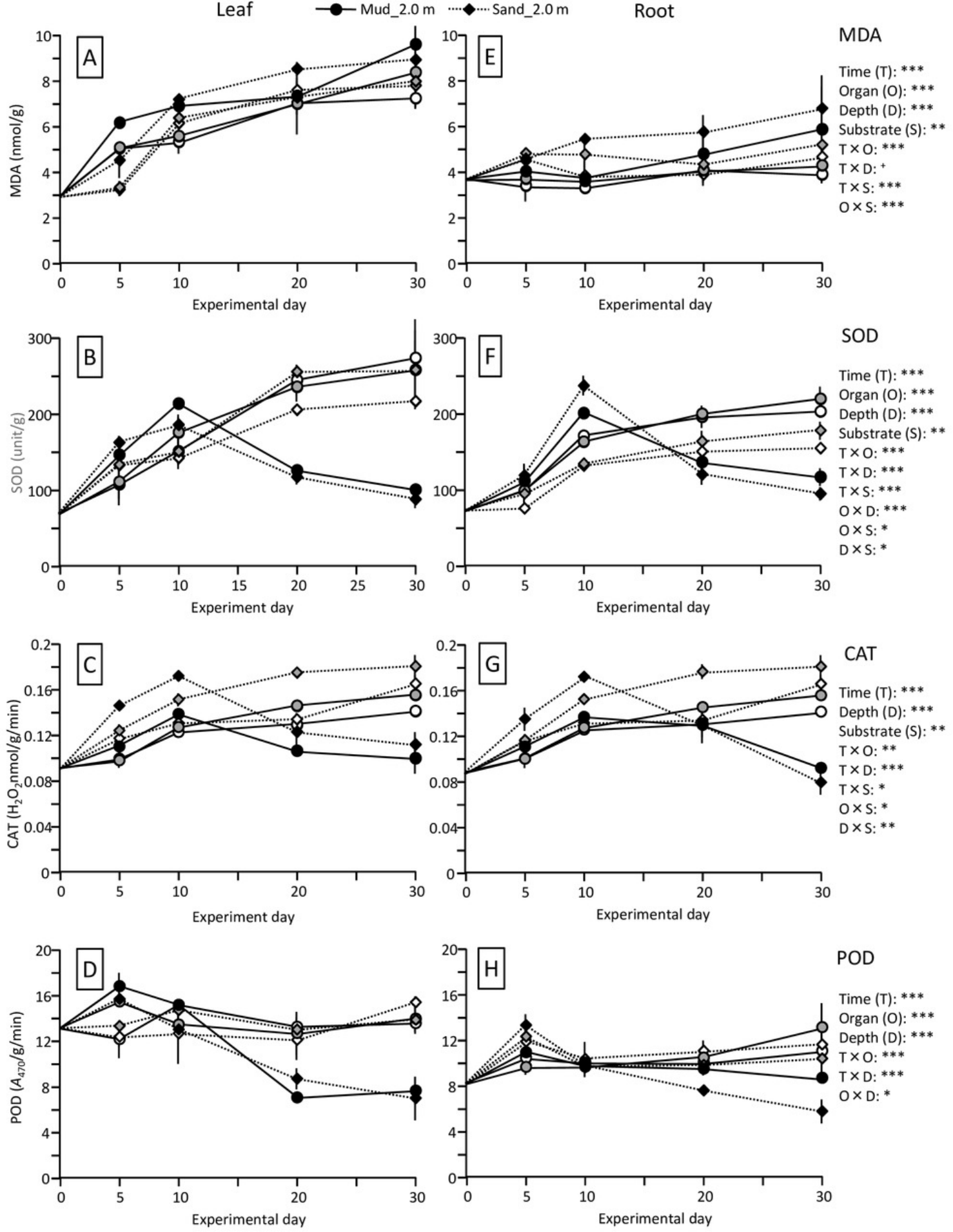
Figure 9

Length (bar) and number (circle) of leaves before and at the end of the field experiment

Error bars denote $1 \mathrm{SD}(n=3)$. Factors with significant effect on length and numbers of

leaves are shown right (***: $p<0.001, * *: p<0.01, *: p<0.05,+: p<0.1$ ). Data of before experiment were not used in the statistical analysis. 


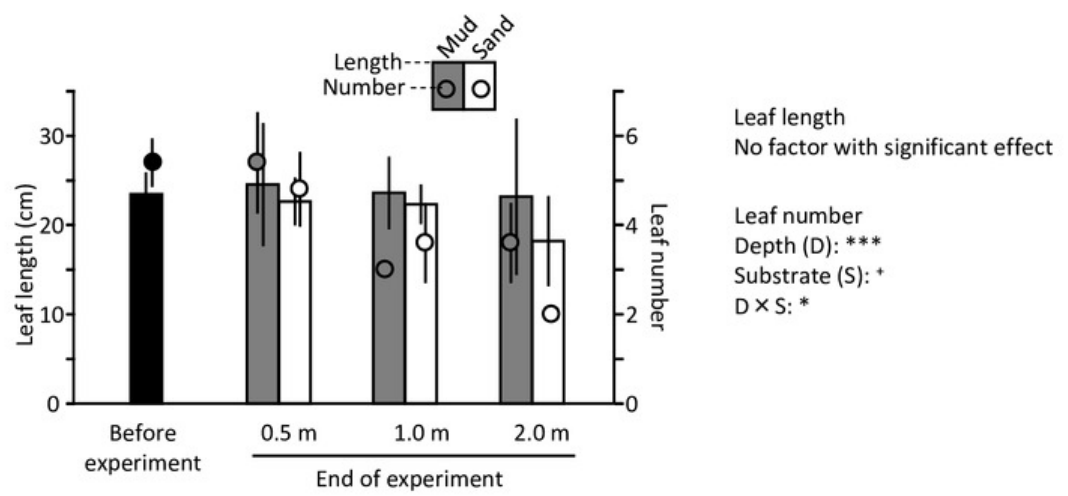




\section{Table $\mathbf{1}$ (on next page)}

Results of split-plot-design analysis of variance (ANOVA) showing the effect of each factor on the physiological indices in the laboratory experiment

Significance of effects are shown by asterisks $\left({ }^{* * *}: p<0.001,{ }^{* *}: p<0.01,{ }^{*}: p<0.05,{ }^{+}: p<\right.$ 0.1 ). Organ and interaction of organ and other factors were not included in the ANOVA for Chl-a and Chl-b 
1

\begin{tabular}{|c|c|c|c|c|c|c|c|c|c|c|c|c|c|}
\hline \multirow[t]{2}{*}{ Factor } & \multirow[t]{2}{*}{$d f$} & \multicolumn{2}{|c|}{ Chl-a } & \multicolumn{2}{|c|}{ Chl-b } & \multicolumn{2}{|c|}{ MDA } & \multicolumn{2}{|l|}{ SOD } & \multicolumn{2}{|l|}{ CAT } & \multicolumn{2}{|c|}{ POD } \\
\hline & & $F$ & $p$ & $F$ & $p$ & $F$ & $p$ & $F$ & $p$ & $F$ & $p$ & $F$ & $p$ \\
\hline Time $(\mathrm{T})$ & 4 & 11.6 & $* * *$ & 3.44 & $*$ & 12.7 & *** & 24.1 & $* * *$ & 4.54 & ** & 22.5 & $* * *$ \\
\hline Organ (O) & 1 & & & & & 463 & $* * *$ & 19.2 & $* * *$ & 132 & $* * *$ & 88.4 & $* * *$ \\
\hline Substrate (S) & 1 & 20.2 & * & 39.3 & $* *$ & 0.88 & & 0.27 & & 0.02 & & 1.81 & \\
\hline $\mathrm{T}^{*} \mathrm{O}$ & 4 & & & & & 3.76 & $*$ & 13.2 & $* * *$ & 1.45 & & 9.90 & $* * *$ \\
\hline $\mathrm{T} * \mathrm{~S}$ & 4 & 5.03 & ** & 4.73 & $*$ & 2.95 & * & 1.63 & & 2.11 & & 2.81 & $*$ \\
\hline $\mathrm{O} * \mathrm{~S}$ & 1 & & & & & 25.2 & $* * *$ & 0.19 & & 1.84 & & 11.1 & $* *$ \\
\hline $\mathrm{T} * \mathrm{O} * \mathrm{~S}$ & 4 & & & & & 2.35 & & 0.56 & & 1.45 & & 3.91 & ** \\
\hline
\end{tabular}

2 


\section{Table 2 (on next page)}

Results of the split-plot-design analysis of variance (ANOVA) that show the effect of each factor on the physiological indices in the field experiment

Significance of effects are shown by asterisks $\left({ }^{* *}: p<0.001,{ }^{* *}: p<0.01,{ }^{*}: p<0.05,{ }^{+}: p<\right.$ 0.1 , results of the interaction among three or more variables were omitted). Organ and interaction of organ and other factors were not included in the ANOVA for Chl-a and Chl-b 
1

\begin{tabular}{|c|c|c|c|c|c|c|c|c|c|c|c|c|c|}
\hline \multirow[t]{2}{*}{ Factor } & \multirow[t]{2}{*}{$d f$} & \multicolumn{2}{|c|}{ Chl-a } & \multicolumn{2}{|c|}{ Chl-b } & \multicolumn{2}{|c|}{ MDA } & \multicolumn{2}{|l|}{ SOD } & \multicolumn{2}{|l|}{ CAT } & \multicolumn{2}{|l|}{ POD } \\
\hline & & $F$ & $p$ & $F$ & $p$ & $F$ & $p$ & $F$ & $p$ & $F$ & $p$ & $F$ & $p$ \\
\hline Time $(\mathrm{T})$ & 3 & 12.0 & $* * *$ & 6.48 & *** & 92.0 & ${ }^{* * *}$ & 121 & *** & 118 & $* * *$ & 37.5 & *** \\
\hline Organ $(\mathrm{O})$ & 1 & & & & & 422 & $* * *$ & 85.3 & $* * *$ & 0.53 & & 213 & *** \\
\hline Depth (D) & 2 & 266 & $* * *$ & 89.4 & $* * *$ & 46.3 & $* * *$ & 43.4 & $* * *$ & 87.8 & $* * *$ & 44.0 & $* * *$ \\
\hline Substrate (S) & 1 & 1.42 & & 1.30 & & 9.70 & ** & 23.1 & $* * *$ & 223 & $* * *$ & 1.32 & \\
\hline $\mathrm{T}^{*} \mathrm{O}$ & 3 & & & & & 36.3 & $* * *$ & 12.2 & $* * *$ & 4.99 & ** & 12.3 & *** \\
\hline $\mathrm{T}^{*} \mathrm{D}$ & 3 & 12.4 & $* * *$ & 5.21 & $* * *$ & 2.02 & + & 103 & $* * *$ & 142 & $* * *$ & 42.9 & *** \\
\hline $\mathrm{T} * \mathrm{~S}$ & 6 & 3.70 & $*$ & 11.0 & $* * *$ & 6.60 & $* * *$ & 8.03 & $* * *$ & 3.16 & * & 2.63 & \\
\hline $\mathrm{O} * \mathrm{D}$ & 2 & & & & & 0.52 & & 20.9 & $* * *$ & 0.66 & & 4.22 & * \\
\hline $\mathrm{O} * \mathrm{~S}$ & 1 & & & & & 20.9 & $* * *$ & 6.21 & $*$ & 5.07 & * & 1.11 & \\
\hline $\mathrm{D}^{*} \mathrm{~S}$ & 2 & 0.25 & & 0.84 & & 0.14 & & 6.09 & $*$ & 7.93 & $* *$ & 1.92 & \\
\hline
\end{tabular}

2 